\title{
LAHAN NGANGGUR TIDAK LAGI TIDUR DENGAN AKAD MUDHARABAH
}

\author{
Nashar \\ nashargalis@gmail.com \\ Institut Agama Islam Negeri (IAIN) Madura
}

\begin{abstract}
Abstrak
Penelitian ini bertujuan untuk mengetahui respon masyarakat petani pada tanaman tebu lahan kering, model pembiayaan syari'ahnya, kesesuaian model pembiayaan syariah dengan akad bagi hasil yang dilakukan oleh pihak penyandang dana, serta dampak model pembiayaan syari'ah pada pertanian tebu lahan kering masyarakat petani di Kecamatan Pegantenan Kabupaten Pamekasan Penelitian ini menggunakan pendekatan kualitatif dengan jenis analisis diskriptif interpretatif. Hasil penelitian menunjukkan bahwa model pembiayaan syariah dengan memakai akad bagi hasil, atas akad kerjasama antara pihak Pemerintah dan pihak PTPN dengan masyarakat petani tebu lahan kering, ternyata memberikan dampak yang positif atau berimplikasi terhadap peningkatan kesejahteran para petani tebu lahan kering di Kabupaten Pamekasan khususnya di Kecamatan Pegantenan. Jadi dengan adanya program pembudidayaan tebu lahan kering bisa memberikan perubahan ekonomi yang signifikan dalam kehidupan petani di wilayah Kecamatan Pegantenan
\end{abstract}

Kata Kunci : keputusan investasi, pendannaan, pembiayaan syari'ah.

\section{Pendahuluan}

Menjamurnya Bank dan Koperasi yang memakai prinsip syariah di Madura saat ini, bisa dikatakan sudah puluhan lembaga keuangan yang berbasis syariah, tentunya hal ini akan memberikan dampak yang baik bagi masyarakat yang membutuhkan pembiayaan sebagai modal kerja dalam menjalankan usahanya. Lembaga keuangan syariah dalam memberikan modal usaha bukan saja bergerak pada bidang industri dan perdagangan, tapi juga memberikan modal di bidang peternakan, bahkan sekarang sudah merambah pada bidang pertanian,yang menarik untuk dikaji dalam fenomena yang terjadi dalam kehidupan masyarakat, yaitu memberikan modal usaha di bidang pertanian ini bukan lembaga keuangan melainkan sebuah Perusahaan Pemerintah yaitu PTPN (Perusahaan Tanaman Perkebunan Nasional). Dimana PTPN dalam rangka memenuhi bahan pemanis (gula Nasional) maka sangat diperlukan adanya kerja sama dengan pihak petani terutama bagi masyarakat yang memiliki lahan tegalan yang kurang produktif bahkan bisa dikatakan lahan nganggur. Dengan semangat gerakan penggunaan modal pembiayaan yang berbasis syariah, tentunya direspon dengan baik oleh pihak petani yaitu dengan memnggunakan akad pembiayaan syariah,termasuk modal usahatani masyarakat yang bergerak dalam budidaya tanaman tebu lahan kering, dengan perkembanganBank dan koperasi syari'ah serta BMT akan membawa angin segar kepada masyarakat Indonesia yang mayoritas beragama Islamkhususnya masyarakat Madura yang dikenal sebagai masyarakat yang taat menjalankan syariat agamanya, agar terhindar dari unsur riba. Masyarakat akan merasa lebih tenang dan tentram jika usaha yang dilakukannya sudah sesuai dengan aturan yang disyari'atkan oleh agama Islam. Masyarakat juga akan lebih merasakan keadilan dalam ekonomi karena sistem syari'ah mempuyai prinsip keadilan.

Disamping lembaga koperasi yang sudah mulai dikenal saat ini, juga berkembang lembaga keuangan mikro berupa BMT (Baitul Maal wat Tamwil) yang merupakan bagian dari koperasi dan juga sebagai lembaga pendukung kegiatan ekonomi masyarakat kecil atau ekonomi lemah dengan berlandaskan sistem ekonomi 
syari'ah Islam. Badan hukum dari BMT dapat berupa koperasi untuk BMT yang telah mempuyai kekayaan Rp 40 juta dan telah siap secara administrasi untuk menjadi koperasi yang sehat dilihat dari segi pengelolaan koperasi dan baik ("thayyiban") dianalisa dari segi ibadah, amalan shalihah para pengurus yang telah mengelola BMT secara syari' ah Islam sebelum berbadan hukum koperasi, BMT dapat berbentuk sebagai KSM (kelompok swadaya masyarakat) yang dapat berfungsi sebagai pra koperasi.

Tidak bisa di elakan lagi bagi pemilik/penyandang dana seperti dalam sebuah pengelolaan usahatani yang bergerak dibidang perkebunan dan pertanian yaitu budidaya tanaman tebu lahan kering yang ada di kabupaten Pamekasan. PTPN (Perusahaan Tanaman Perkebunan Nasional) juga berkeinginan untuk melaksanakan pembiayaan dengan yang syariah yaitu dengan cara yang lebih menguntungkan, tentunya produk yang ditawarkan lebih beragam dibanding dengan akad konvensional salah satunya dengan modal pembiayaan memakai akad mudharabah (bagi hasil).

Dalam akad mudharabah menggunakan sistem bagi hasilnya itu ditentukan sesuai dengan perjanjian yang sudah disepakati. Dengan adanya mekanisme seperti itu, apabila terjadi suatu kerugian yang tidak disebabkan oleh kelalaian pengelola (mudharib) maka kerugian akan ditanggung oleh pihak Penyandang Dana yaitu PTPN. Namun sebaliknya, apabila kerugian disebabkan oleh kelalaian pihak pengelola maka kerugian ditanggung pengelola. Hal tersebut harus dicantumkan di dalam akad, dengan adanya perjanjian seperti itu maka kedua belah pihak tidak ada yang merasa dirugikan.

Penyaluran dana dengan akad mudharabah ini berupa pembiayaan modal kerja. Pembiayaan modal kerja merupakan pembiayaan jangka pendek yang diberikan kepada petani untuk membiayai kebutuhan modal kerja, berdasarkan prinsip syari'ah. Dalam hal iniPTPN yang bertujuan untuk mensejahterakan para petani dengan jalan memberikan bantuan modal kerja pada semua masyarakat yang memiliki lahan atau mau menyewa lahan untuk budidaya tanaman tebu lahan kering.pada saat ini di dukung oleh Pemerintah Daerah dengan satu kebijakan tanaman tebu sebagai opsi tanaman tembakau, mengingat hal ini merupakan yang berbeda dengan lembaga keuangan dan mau melaksanakan usaha investasi pembiayaan dengan memakai akad Mudharabah. Sehingga yang demikian akan sangat menarik untuk dilakukan pengkajian mengenai modal kerja yang diberikan oleh pihak PTPNyang bukan lembaga keuangan kepadamasyarakat petani tebu lahan kering di Kabupaten Pamekasan.

\section{Landasan Teori}

\subsection{Usaha Tani}

Tanaman tebu (Saccharum officinarum L) lahan kering merupakan sejenis tanaman rumput-rumputan (Graminae) yang merupakan tanaman asli tropika basah, namun masih dapat tumbuh baik dan berkembang di daerah subtropika, pada berbagai jenis tanah dari daratan rendah hingga ketinggian $1.400 \mathrm{~m}$ diatas permukaan laut (dpl). Tanaman tebu lahan kering merupakan tanaman opsi sebagai tanaman alternatif di lahan kering (serapan air rendah).Pemerintah Pamekasan mengajak para petani di Daerah kecamatan untuk segera beralih ke budidaya tanaman tebu.Alasannya, tanaman tersebut prospeknya lebih cerah dibandingkan tanaman tembakau yang harganya sudah tidak stabil dan terus menurun.

Tanaman tebu lahan kering ini menurut hasil survey yang dilakukan dinas kehutanan dan perkebunan bekerjasama dengan PTPN memiliki kecocokan dengan karakter pertanahan di wilayah Madura sehingga petani diharapkan lebih menguntungkan dengan membudidayakan tanaman tebu lahan kering dan bisa merubah perekonomian masyarakat menjadi lebih baik bagi masyarakat yang memiliki tanah yang tidak lagi produktif untuk tanaman tembakau. Dengan adanya tanaman opsi sebagai tanaman alternatif di wilayah yang tidak lagi produktif untuk tanaman 
tembakau didukung oleh political will pemerintah melalui dinas kehutanan dan perkebunan, maka petani banyak yang merespon positif terhadap tanaman opsi ini sebagai usahatani.

\subsection{Kelayakan Investasi Tanaman Tebu Lahan Kering di Madura}

Menurut Kasmir, studi kelayakan bisnis adalah suatu kegiatan penelitian yang dilakukan secara mendalam tentang rencana bisnis, dalam rangka menentukan layak atau tidaknya rencana bisnis tersebut untuk dijalankan. Layak dalam arti akan memberikan keuntungan tidak hanya terhadap perusahaan yang menjalankannya, akan tetapi bagi investor, kreditor, pemerintah dan masyarakat secara luas.

Pulau Madura memang identik dengan Pulau Garam, yang jelas terasa asin. Namun saat ini, Pulau Madura juga berpotensi menjadi Pulau Tebu, yang sudah tentu berasa manis. Hal itu, tak lepas dari hasil kajian Pusat Penelitian Perkebunan Gula Indonesia (P3GI), di mana kurang lebih ada lahan seluas 65.000 hektar yang tersebar di Kabupaten Bangkalan dan Sampang punya potensi untuk budidaya pengembangan tanaman tebu. Bahkan dari hasil uji coba penanaman yang telah dilakukan PG Candi Baru Sidoarjo, di Kecamatan Omben, Ketapang dan Jrengik Kabupaten Sampang per hektarnya mampu menghasilkan 70 - 90 ton tebu siap giling. Namun, tidak seluruh lahan yang berpotensi akan dimanfaatkan seluruhnya. Kalau 20 ribu ha saja sudah bisa untuk satu perusahaan Gula (PG).Dengan rendemen 8, bisa menambah produksi gula sebesar 700 ribu ton.

\subsection{Pembiayaan}

Pembiayaan merupakan aktivitas bank syariah dalam menyalurkan dana kepada pihak lain selain Bank, berdasarkan prinsip syariah. Penyaluran dana dalam bentuk pembiayaan didasarkan pada kepercayaan yang diberikan oleh pemilik dana kepada pengguna dana. Pemilik dana percaya kepada penerima dana, bahwa dana dalam bentuk pembiayaan yang diberikan pasti akan terbayar. Penerima pembiayaan mendapat kepercayaan dari pemberi pembiayaan, sehingga penerima pembiayaan berkewajiban untuk mengembalikan pembiayaan yang telah diterimanya sesuai dengan jangka waktu yang telah diperjanjikan dalam akad pembiayaan.

Didalam perbankan syariah istilah pembiayaan berbeda dengan kredit yang ada di bank konvensional, dalam perbankan syariah, return atas pembiayaan tidak dalam bentuk bunga akan tetapi bisa berbentuk bagi hasil, margin atau ujroh sesuai dengan akad-akad yang disediakan di Bank syariah. Bank syariah menyalurkan dananya kepada nasabah dalam bentuk pembiayaan.Sifat pembiayaan bukan utang piutang, tetapi merupakan investasi yang diberikan bank kepada nasabah dalam melakukan usaha.Pembiayaan yang diberikan oleh bank syariah berfungsi membantu masyarakat dalam memenuhi kebutuhan dalam meningkatkan usahanya. Masyarakat merupakan individu, pengusaha, lembaga, badan usaha, dan lain-lain yang membutuhkan dana.Adapun fungsi pembiayaan antara lain:

\subsection{Mudharabah}

\section{a. Pengertian Mudharabah}

Mudharabah adalah penanaman dana dari pemilik dana (shohibul maal) kepada pengelola dana (mudharib) untuk melakukan kegiatan usaha tertentu, dengan pembagian menggunakan metode bagi hasil (profit sharing) atau metode bagi pendapatan (revenue sharing) antara kedua belah pihak berdasarkan nisbah yang telah disepakati sebelumnya.Mudharabah merupakan wahana utamabagi lembaga keungan Islam untuk memobilisasi dana masyarakat dan untuk menyadikan berbagai fasilitas, antara lain fasilias pembiayaan, bagi para pengusaha.Definisi lain menyatakan investasi 
mudharabah yaitu pembiayaan yang disalurkan oleh Bank syariah kepada pihak lain untuk usaha yang produktif. Adapun menurut Syafi'I Antonio mudharabah adalah sebagai akad kerja sama usaha antara dua pihak di mana pihak pertama (shohibul maal) menyediakan seluruh (100\%) modal, sedangkan pihak lain sebagai pengelola.Menurut Dwi Suwiknyo mudharabah adalah akad kerja sama usaha antara dua pihak; pihak pertama (pemilik dana) menyediakan seluruh dana, sedangkan pihak kedua (pengelola dana) bertindak selaku pengalola. Keuntungan usaha ini dibagi antara mereka sesuai kesepakatan, sedangkan kerugian finansial hanya ditanggung oleh pengelola dana.

\section{b. Landasan Hukum Mudharabah}

Menerapkan sistem bagi hasil dan perdagangan, sebagai landasan hukumnya dari akad syariah mudharabah diantaranya adalah sebagai berikut

1) Al-qur'an

Surat an-Nisa', al-Jumu'ah, dan al-Baqarah mempunyai makna yaitu samasama mendorong kaum muslimin untuk melakukan suatu upaya perjalanan usaha.

Q.S. an-Nisa' (4) : 29 :

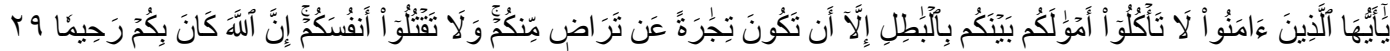

Artinya: "Hai orang-orang yang beriman, janganlah kamu saling memakan harta sesamamu dengan jalan yang batil, kecuali dengan jalan perniagaan yang berlaku dengan suka sama-suka di antara kamu. Dan janganlah kamu membunuh dirimu; sesungguhnya Allah adalah Maha Penyayang kepadamu".

Selain surat an-Nisa', yang dijadikan landasan juga adalah surat al-Jumu'ah: (62) : 10, al-Muzammil (73) : 20, sertaal-Baqarah mempunyai makna yang sama yaitu mendorong kaum muslimin untuk melakukan suatu upaya kegiatan usaha.

2) Al-Hadits

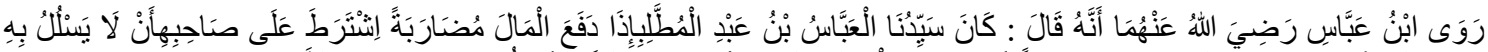

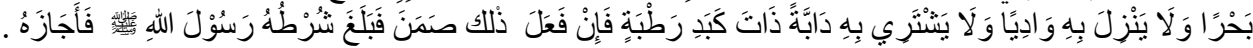

Artinya : "Di riwayatkan dari Ibnu Abbas bahwa Sayyidina Abbas Bin Abdul Mutallib jika memberikan dana ke mitra usaha secara mudharabah ia mensyaratkan agar dananya tidak dibawa mengarungi lautan, menuruni lembah yang berbahaya atau membeli ternak, jika melayani pelaturantersebut yang bersangkutan bertanggung jawab atas dana tersebut, disampaikan syarat-syarat tersebut kepada Rasulullah SAW. dan Rasulullahpun membolehkannya". (HR. Thabrani).

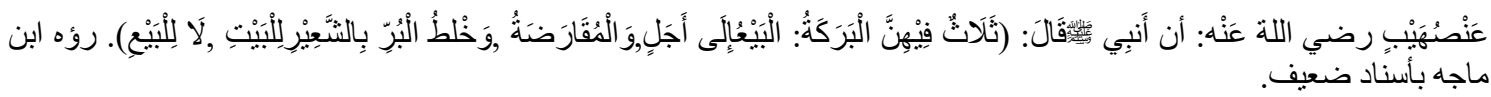

Artinya: "Dari Sholeh Bin Shuhaib dari bapaknya Rasulullah SAW. bersabda, tiga hal yang di dalamnya terdapat keberkatan: 1. Jual beli secara tangguh, 2. Muqaradhah(Mudharabah), 3. Dan mencampur gandum dengan tepung untuk keperluan rumah bukan untuk di jual" (HR. IbnuMajah). 


\subsection{Bagi hasil}

Bagi hasil adalah bentuk return (perolehan aktivitas uasaha) dari kontrak investasi, dari waktu ke waktu tidak pasti dan tidak tetap pada Bank Islam. Besarkecilnya perolehan kembali, tergantung pada hasil usaha yang sebenarnya di peroleh Bank Islam.pengertian yang lain dinyatakan bahwa bagi hasil adalah pembagian atas hasil usaha yang telah dilakukan oleh pihak-pihak yang melakukan perjanjian yaitu pihak nasabah dan pihak Bank syari'ah.Dari pengertian ini bisa disimpulkan bahwa bagi hasil merupakan distribusi beberapa bagiandari laba yang telah dilakukan oleh pihak-pihak yang melakukan perjanjian yaitu pihak nasabah sebagai pengelola dana (mudharib) dan pihak Bank syariah sebagai pemilik modal (sholibul maal).

Dalam sistem budidaya tanaman tebu lahan kering, bagi hasil merupakan suatu mekanisme investasi yang dilakukan oleh pihak PTPN dengan masyarakat petani dalam upaya untuk memperoleh hasil dan membagikannya kembali kepada petani atau pengelola dana sesuai dengan kontrak yang disepakati bersama di awal kontrak antara PTPN dan masyarakat petani tebu. Dimana besarnya penentuan porsi bagi hasil antara kedua belah pihak ditemukan sesuai dengan kesepakatan bersama, dan harus terjadi dengan adanya kerelaan oleh masing-masing pihak tanpa adanya unsur paksaan.

\section{Pembahasan}

Pembahasan dari temuan penelitian ini, pada Pembiayaan modal kerja pada tanaman tebu lahan kering merupakan pembiayaan yang diberikan kepada masyarakat petani tebu untuk membiayai modal kerja usahanya berdasarkan prinsip-prinsip syariah, yang dijadikan acuan oleh PTPN mengenai konsep syariah dalam memberikan modal, khususnya pembiayaan modal kerja pertanian tebu lahan kering. Dalam hal ini berlandaskan pada fatwa Dewan Syariah Nasional (DSN) No. 07/DSN-MUI/IV/2000 tentang pembiayaan mudharabah,dengan ketentuan pertama pembiayaan telah dilaksanakan dari poin 1 (satu) sampai poin 9 (sembilan), hanya poin 10 (sepuluh) yang tidak diatur dalam perjanjian pembiayaan tersebut. Kedua mengenai rukun dan syarat pembiayaan sebagaimana yang diatur dalam fiqih dan juga dalam fatwa DSN sudah terpenuhi, dan ketiga mengenai ketentuan hukum yang dipersyaratkan juga telah dinyatakan dalam kontrak perjanjian yang telah disepakati dan ditandatangani oleh kedua belah pihak.

Hal-hal yang dijadikan dasar oleh PTPN dalam pemberian pembiayaan modal kerja melalui Dinas Pentanian dan Perkebunan Kabupaten Pamekasan antara lain:

a. Dari segi pengelolaannya. Kebutuhan modal kerja masing-masing dari petani pasti berbeda sesuai dengan lahan yang di peruntukkan pada tanaman tebu. Salah satu yang menjadi pertimbangan dalam menentukan pemberian modal ini yaitu segi penggarapan awal, kalau lahan yang diperuntukkan merupakan lahan yang masih baru memulai penggarapannya dimana lahannya masih banyak ditumbuhi pohon-pohon maka berbeda biaya modal dengan lahan yang sudah siap untuk ditanami tebu dan pihak PTPN sudah bisa menentukan seberapa banyak jumlah kebutuhan petani tersebut untuk mendapat bantuan modal.

b. Skala luasnya lahan. Besarnya kebutuhan modal kerja tanaman tebu sangat tergantung kepada skala luas lahannya yang mau ditanami tebu. Semakin luas lahannya yang mau ditanami tebu, kebutuhan modal akan semakin besar. Besar kecilnya luas lahan mempengaruhi terhadap jumlah bantuan modal kerja petanidari PTPN sesuaiakan kebutuhan modal kerja petani.

c. Lokasi tempat usaha. Harus sesuai dengan lahan yang diperuntukaan untuk tanaman tebu, dan sesuai dengan petunjuk Pemerintah Daerah Kabupaten Pamekasan, yaitu daerah atau lahan yang nganggur dan kurang produktif 
karena kurangnya resapan airnya. Lokasi ini juga menjadi salah satu aspek pertimbangan yang dijadikan dasar PTPN dalam memberikan pembiayaan modal kerja.

d. Prospek tanaman tebu. Usaha tani tanaman tebu tentunya mempunyai prospek kedepan dalam rangka pemenuhan kebutuhan bahan pemanis yang dibutuhkan oleh masyarakat. Bahwa usaha tersebut diyakini mampu memberikan keuntungan di masa yang akan datang baik bagi petani maupun pihak PTPN, dan tentunya usahatersebut tidak dilarang dalam Islam.

e. Amanah.Petani penerima pembiayaan modal kerja harus memiliki sifat jujur dan amanah.Petani harus memiliki sifat terpujiselama menjadi anggota kelompok tani maupun individutidak pernah melakukan perbuatan yang kurang baik dalam kehidupan masyarakat.

Akad yang digunakan adalah akad mudharabah muqayyadah di mana pembagian porsi keuntungan (bagi hasil) disesuaikan dengan kesepakatan waktu melaksanakan akad. Mudharabah muqayyadah ini merupakan kerjasama antara pihak PTPN sebagai (shahibul maal) dengan petani tebu sebagai (mudharib) dalam budidaya tanaman tebu lahan kering, PTPN bertindak sebagai pemilik dana dan petani bertindak selaku pengelola dana. Dalam pelaksanaannya menggunakan akad mudharabah muqayyadah, pemberian pembiayaan ini mempunyai akad yang berlaku dalam pembatasan atas jenis usaha, waktu dan tempat usaha, sehingga jenis dan ruang usaha yang akan dilakukan oleh mudharib (petani penerima pembiayaan) sudah ditentukan diawal akad,dengan demikian pihak PTPN selaku Shahebul Maal lebih mudah dalam melakukan kegiatan monitoring terhadap usaha tanaman tebu yang dilakukan petani sebagai Mudharib.

Bagi hasil adalah pembagian atas hasil usaha yang telah dilakukan oleh pihakpihak yang melakukan perjanjian yaitu pihak PTPN dan pihak petani. Dalam hal ini terdapat dua pihak yang melakukan perjanjian usaha. Maka hasil atas usaha yang dilakukan oleh kedua belah pihak atau salah satu pihak, akan dibagi sesuai porsi masing-masing pihak yang melakukan akad perjanjian. Pembagian hasil usaha tani antara petani dan pihak PTPN ditetapkan menggunakan nisbah. Nisbah yaitu prosentase yang disetujui oleh kedua belah pihak yang menentukan bagi hasil atas usaha yang dikerjasamakan yaitu budidaya tanaman tebu lahan kering.

Cara penentuan bagi hasil didasarkan pada kesepakatan antara kedua belah pihak yaitu pihak PTPN dan pihak petani. Kemudian pihak PTPN memberikan penawaran awal tentang nisbah bagi hasil dari pembiayaan modal kerja tersebut.Misalkan bagi hasil yang ditawarkan 40:60 artinya bagi hasil untuk PTPN 40\% dan bagi hasil untuk pengelola $60 \%$. Penawaran ini tergantung kesepakatan antara pihak PTPN dengan Petani tebu lahan kering, tidak terpaku pada yang ditawarkan PTPN sebelumya karena petani berhak menentukan nisbah bagi hasil yang akan disepakatinya.

Untuk penawaran PTPN biasanya ada yang 40:60, 34:66, 30:70 dan ada yang 50:50. Namun itu bisa berubah tergantung pada kesepakatan petani dan pihak PTPN pada waktu melakukan akad.Petani berhak menentukan berapa besaran bagi hasil yang disanggupinya.Kesepakatan itu terjadi pada saat akad ditandatangani, dan besarnya prosentase bagi hasil harus tertera dalam kontrak akad.

Setelah Petani menerima bantuan pembiayaan modal kerja, maka petani terikat dengan perjanjian yang telah disepakati dan mempunyai kewajiban untuk mematuhi akad kerjasama tersebut beserta bagi hasil yang di perjanjikan dengan pihak PTPN. Petani dan pihak PTPN melaksanakan bagi hasil setelah selesai pelaksanaan panen dan sudah dipasarkan serta penghasilannya sudah diterima oleh kedua belah pihak. 
Usaha meminimalkan resiko yang mungkin terjadi, pihak PTPN melakukan langkah-langkah sebagai berikut: pertama,PTPN melakukan kontrol secara berkala terhadap usaha yang dilakukan petani baik secara langsung maupun secara perwakilan yang dipercaya pihak PTPN yaitu Pemerintah Daerah melalui Dinas Perkebunan dan Kehutanan Kabupaten Pamekasan. Pengawasan dan penyuluhan harus dijalankan demi menjaga perkembangan dari pertumbuhan tanaman tebu, sehingga masyarakat tidak dirugikan dengan tanaman baru yaitu tanaman tebu. Sehingga secara otomatis pihak perusahaan juga terhindar dari kerugian. Kedua, ikut memasarkan hasil panen yang dihasilkan oleh petani yaitu memediasi antara pihak petani dan pihak perusahaan, karena pihak petani belum tahu cara dan sistem penjualan hasil panennya.

Hasil penelitian menunjukkan bahwa cara pemberian modal kerja, PTPN \sesuai dengan syariah, rukun dalam transaksi mudharabah muqayyadah ini telah terpenuhi, yaitu; pertama, transaktor. Transaktor dalam pemberian modal kerja yaitu kedua belah pihak yang terlibat yaitu PTPN sebagai pemilik dana (shohibul maal) dan Petani sebagai pihak pengelola dana (mudharib). Kedua belah pihak telah memenuhi kriteria kompetensi beraktivitas. Kriteria kompetensi tersebut antara lain mampu membedakan yang baik dengan yang buruk dan tidak sedang mengalami keadaan tercekal dan pailit.

Kedua, objek mudharabah muqayyadah. Objeknya dalam pemberian modal kerja akad mudharabah muqayyadah ini yaitu modal dan usaha. PTPN menyerahkan modal sebagai objek mudharabah dan Petani menyerahkan kerjanya (usaha) sebagai objek mudharabah. Modal yang diberikan oleh pihak PTPN yaitu berbentuk barang yang dibutuhkan oleh petani yang jumlahnya di kalkulasi dengan jumlah uang yang dibutuhkan oleh petani sebagai modal kerja (usaha).

Ketiga, ijab dan qabul. Persetujuan pihak PTPN dengan pihak petani terwujud dalam prinsip rela sama rela (an-taraddin minkum). Dalam hal ini, PTPN dan petani rela bersepakat dalam akad mudharabah muqayyadah.PTPN setuju dengan peranannya memberikan dana (modal), sedangkan petani setuju memberikan kerjanya serta antara pihak PTPN dan pihak Petani juga sepakat dengan besarnya porsi bagi hasil sebagaimana yang tercantum dalam perjanjian transaksi (akad). Akad yang ada berbentuk perjanjian tertulis hitam di atas putih dan memiliki kekuatan hukum yang mengikat kedua belah pihak dengan segala ketentuannya.

Sistem bagi hasil yang diperjanjikan sesuai dengan kesepakatan kedua belah pihak dan tertera dalam akad yang telah ditandatangani.Sebelum disepakati porsi bagi hasil tersebut pihak PTPN memberikan penawaran kepada Petani.Dengan nisbah sebesar 40\%:60\% artinya 40\% keuntungan pihak PTPN (shahibul maal)dan 60\% keuntungan Petani sebagai pengelola (mudharib)atau ada juga nisbahnya sebesar $34 \%: 66 \%$ ada juga nisbahnya sebesar 30\%: 70\% dan bahkan bisa $50 \%: 50 \%$. petani bisa melakukan penawaran sesuai dengan kehendak petani dan tidak terikat terhadap penawaran pihak PTPN sebelum ditandatanganinya akad.

Sebelum menyetujui nisbah keuntungan, pihak PTPN melakukan analisa terhadap petani.Analisa tersebut meliputi 5C (character, capasity, capital, commitment, dan collateral).PTPN menilai karakter dari petani yang akan diberikan pembiayaan modal kerja. Sifat dan kepribadian petani, kejujurannya serta watak petani dinilai. Mulai dari berkas pengajuannya melalui kelompok tani yang diisi dengan keadaan yang sebenarnya menunjukkan bahwa petani tersebut jujur, dan nilainya akan sama dengan setelah dilakukan survei dari pihak PTPN.

Kemampuan petani juga dinilai dalam menjalakan usaha dalam membudidayakan tanaman tebu lahan kering.Seberapa besar petani tersebut mampu mengelola usaha tanaman tebu yang dibiayai PTPN serta nantinya mampu merawat tanaman tebu sampai masa panen sehingga modal yang diberikan bisa memberikan keuntungan dan bisa mengangkat perekonomiannya. Selain itu petani juga memiliki 
komitmen dari apa yang diperjanjikan dalam akad. Petani berkomitmen menjalankan usahanya dengan baik dan juga berkeinginan kuat untuk meningkatkan kesejahteraan keluarga dengan usaha tani tanaman tebu lahan kering.

Selain itu PTPN juga akan menilai luasnya lahan yang akan ditanami tebu dalam perjanjian kerjasama tersebut. Luas lahan ini selain untuk mengikat petani juga digunakan PTPN sebagai analisa awal dalam memenuhi kebutuhan bahan baku gula atau stok yang harus dipenuhi oleh pihak PTPN dalam memenuhi kebutuhan gula secara Nasionalapabila luas pertanian sudah mencukupi untuk produksi gula selama satu tahun sudah cukup maka pihak PTPN tidak akan melaksanakan kontrak baru dengan petani lain tapi kalau masih belum memenuhi stok kebutuhan gula nasional maka secepatnya pihak PTPN akan melakukan kerjasama lagi dengan pihak yang belum melakukan kerjasama untuk memenuhi stok kebutuhan gula Nasional.

\section{Penutup}

Berdasarkan pada temuan penelitian dan pembahasan dari sudut kajian per item pertanyaan yang di ajukan kepada para petani tebu atau pengelola dana (Mudharib). Tentang akad sistem bagi hasilnya akad mudharabah,cara menentukan besar kecilnya bagi hasil serta kesesuaian akad bagi hasil dengan ajaran Islam, dapat disimpulkan sebagai berikut :

a. Akad yang digunakan adalah akad mudharabah muqayyadah di mana pembagian porsi keuntungan (bagi hasil) disesuaikan dengan kesepakatan waktu melaksanakan akad. Mudharabah muqayyadah ini merupakan kerjasama antara pihak PTPN sebagai (shahibul maal) dengan petani tebu sebagai (mudharib) dalam budidaya tanaman tebu lahan kering. Dalam pelaksanaannya menggunakan akad mudharabah muqayyadah di mana pemberian pembiayaan ini mempunyai akad yang berlaku dalam pembatasan atas jenis usaha, waktu dan tempat usaha, sehingga jenis dan ruang usaha yang akan dilakukan oleh mudharib (petani penerima pembiayaan) sudah ditentukan diawal akad. Dengan demikian pihak PTPN selaku Shahebul Maal lebih mudah dalam melakukan kegiatan monitoring terhadap usaha tanaman tebu yang dilakukan petani sebagai Mudharib.

b. Cara penentuan bagi hasil didasarkan pada kesepakatan antara kedua belah pihak yaitu pihak PTPN sebagai (shahibul maal)dan pihak petanisebagai (mudharib). Kemudian pihak PTPN memberikan penawaran awal tentang nisbah bagi hasil dari pembiayaan modal kerja tersebut. Misalkan bagi hasil yang ditawarkan 40:60 artinya bagi hasil untuk PTPN 40\% dan bagi hasil untuk pengelola $60 \%$. Penawaran ini tergantung kesepakatan antara pihak PTPN dengan Petani tebu lahan kering, tidak terpaku pada apa yang ditawarkan PTPN sebelumya karena petani berhak menentukan nisbah bagi hasil yang akan disepakatinya.

c. Dari hasil penelitian diatas, akad kerjasama antara PTPN dengan pengeloladana (mudharib) sudah sesuai dengan yang disyariatkan islam. Sebab kedua-duanya sudah melaksanakan akad yang ditentukan oleh syariat islam, misalnya dalam menentukan bagi hasil meskipun persentasenya berbeda akan tetapi yang jelas diawal perjanjian kerjasama usaha tersebut sudah disepakati dan yang pasti sudah saling menerima hasil kesepakatan tersebut.

Jadi cara penentuan bagi hasil di atas sudah sesuai dengan konsep syariah dilihat dari rukunnya yaitu:

1) Transaktor, yang bertransaksi adalah PTPN sebagai(shohibul maal) dengan petani tebu sebagai(mudharib).

2) Ada objek dalam akad mudharabah muqayyadah, yaitu modal dan usaha

3) Ada kesepakatan Ijab dan qabul (berupa penandatangan akad kerjasama). 


\section{Daftar Pustaka}

Ahmad bin Husaimi Sy. Syarah: Fathul Qurrib Al-Mujib (sangkokuruh: Al-Hurumain, 2015.

Amang, B. Perkembangan Ekonomi Pertanian Nasional 1969-1994, (Jakarta: Perhepi, 1995).

An-Nabawi, Taqiyuddin.Membangun Sistem Ekonomi Alternatif Perspektif Islam. Surabaya: Risalah Gusti, 2009.

Antonio, M. Syafi'i. Bank Syariah: Analisis Kekuatan, Peluang, Kelemahan dan Ancaman. Yogyakarta: Ekonosia, 2002.

Arikunto, Suharsimi. Manajemen Penelitian. Jakarta: Rineka Cipta, 2010.

Ascarya.Akad dan Produk Bank Syariah. Jakarta: PT. Raja Grafindo Persada, 2008.

Badan Agribisnis Departemen Pertanian. 1999. Investasi Agribisnis Komoditas Unggulan Tanaman Pangan dan Holtikultura.Kanisius.Yogyakarta.

Dahlan, Ahmad. Pengantar Ekonomi Islam. Purwokerto: STAIN Press, 2010.

Departemen Agama RI.Al-Quran dan Terjemahnya. Bandung: CV. J-Art, 2005.

Halim, Abdul. 2005. Analisis Investasi. Jakarta. Salemba Empat.

Hasbi, Ramli. Teori Dasar Akuntansi Syariah. Jakarta: Renaisan, 2005.

Hermanto F. 1993. Ilmu Usahatani. Jakarta. Penebar Swadaya.

Hub De jonge, Madura dalam empat zaman: Pedagang, perkembangan ekonomi, dan Islam. (Jakarta: Gramedia, 1989)

Ifham, Ahmad Sholihin. Pedoman Umum Lembaga Keuangan Syariah. Jakarta: PT. Gramedia Pustaka Utama, 2010.

Iska, Syukri. Sistem Perbankan Syariah di Indonesia dalam Perspektif Fikih Ekonomi. Yogyakarta: Fajar Media Press. 2012.

Ismail.Keuangan dan Investasi Syariah: Sebuah Analisa Ekonomi. tt: Sketsa, 2010.

Karim, Adiwarman. Ekonomi Mikro Islami, Jakarta: Rajawali Press, 2010.

Kasmir.Pengantar Manajemen Keuangan. Jakarta: Kencana, 2010.

M Mankiw, Gregory.Pengantar Ekonomi Mikro Edisi Tiga. Jakarta: Salemba Empat, 2011.

Muhammad. Teknik Perhitungan Bagi Hasil dan Profit Margin pada Bank Syariah. Yogyakarta: UII Pres, 2004.

Muthaher, Osmad. Akuntansi Perbankan Syariah. Yogyakarta: Graha Ilmu, 2012.

Nunir, Misbahul dan A. Djalaluddin.Ekonomi Qur'ani, Doktrin Reformasi dalam Al-qur'an. Malang: UIN Malang Press, 2006.

Nurhayati, Fitri dan Ika Saniyati R.Koperasi Syariah. Surakarta: PT. Era Intermedia, 2008.

Patilima, Hamid. Metode Penelitian Kualitatif. Bandung: Alfabeta, 2005.

Prastowo, Dwi., dan Rifka Julianty.Analisis Laporan Keuangan Konsep dan Aplikasi, Yogyakarta. UPP STIM YKPN, 2008.

Radar Madura (Jawa Pos) 2/9/2001 dan 22/9/2001

Rifqi, Muhammad. Akuntansi Keuangan Syariah: Konsep dan Implementasi PSAK Syariah. Yogyakarta: P3EI Press, 2008.

Rivai, Veithzal, dan Arifin Arvian. Islamic Banking: Sebuah Teori, Konsep, dan Aplikasi. Jakarta: PT Bumi Aksara, 2010.

Salvatore, Dominick. Teori dan Soal Mikroekonomi.Jakarta: Erlangga, 2006.

Soekartiwi. Soeharjo A. Dillon JL. Hardaker JB. 2000. Ilmu Usahatani dan Penelitian untuk Pengembangan Petani Kecil. Jakarta. UI.Press.

Sukirno, Sadono. Ekonomi Mikro,Teori Pengantar, Jakarta: PT Raja Grafindo Persada, 2005.

Suprayitno, Eko. Ekonomi Mikro Perspektif Islam, Malang: UIN Malang Press, 2008.

Suwiknyo, Dwi. Pengantar Akuntansi Syariah: Lengkap dengan Kasus-kasus Penerapan PSAK Syariah Untuk Perbankan Syariah. Yogyakarta: Pustaka Pelajar, 2010.

Syeh A. Ianatul Ahkam, Islamic Banking: Sebuah Teori Konsep dan Aplikasi (Jakarta, Bumi Aksara, 2010

Wiroso.Akuntansi Transaksi Syariah. Jakarta: Ikatan Akuntansi Indonesia, 2011. 
TARGET : JURNAL MANAJEMEN DAN BISNIS | e-ISSN : 2715-9361 | Vol. 2 No. 1 | Juni 2020 DOI https://doi.org/10.30812/target.v2i1.693

Yahya, R. Akuntansi Perbankan Syariah Teori dan Praktek Kontemporer. Jkt: Erlangga, 2009. Zainuddin. Hukum Perbakan Syariah, Jakarta: Sinar Grafika, 2008. 